\title{
Gastrin cell function in familial multiple endocrine neoplasia type I
}

\author{
C B H W LAMERS, J I ROTTER, AND J B M J JANSEN \\ From the Department of Gastroenterology and Hepatology, University Hospital, Leiden, St Radboud Hospital, \\ Nijmegen, The Netherlands, and the Division of Medical Genetics, Departments of Medicine and Pediatrics, \\ Cedars-Sinai Medical Center, Los Angeles, California, USA
}

SUMmARY Recent studies have suggested that patients with multiple endocrine neoplasia type I (MEN I) may have abnormal serum gastrin secretion in the absence of gastrin producing tumours. G-(gastrin) cell function by three provocation tests in 20 patients with hyperparathyroidism from six MEN I-families were studied: each patient was an obligate carrier of the MEN I-gene. The serum gastrin response to secretin was used to identify the presence of gastrinoma, that to a test meal of G-cell hyperfunction of the antral and/or duodenal mucosa, and that to bombesin to differentiate antral from duodenal G-cell hyperfunction. Seven patients had basal hypergastrinaemia and hyperchlorhydria. These patients had increased serum gastrin responses to secretin $(p<0 \cdot 01)$ and to bombesin $(p<0 \cdot 02)$, but normal postprandial responses. In the 13 normogastrinaemic patients the responses to the three stimuli were normal. In families with MEN-I gastrinoma is the only endocrine disorder accounting for abnormal gastrin secretion. G-cell function is normal in obligate carriers of the MEN I-gene.

Multiple endocrine neoplasia type I (MEN-I) is an autosomal dominant inherited disorder characterised principally by tumours of the parathyroid glands, the pituitary, and the pancreatic islets. ${ }^{1-4}$ Less common are tumours of the adrenal cortex and various types of carcinoids. An individual carrying the MEN-I gene may have one or any combination of these tumours. In such patients hypergastrinaemia is usually caused by gastrin producing tumours leading to marked gastric hypersecretion and severe ulcer, the Zollinger-Ellison syndrome..$^{2-\infty}$ Other abnormalities of gastrin secretion have recently been described, however, in patients with the MEN I-syndrome without gastrin producing tumours. Such patients showed an enlarged serum gastrin response to a standard test meal suggesting hyperplasia or hyperfunction of antroduodenal G-(gastrin) cells. ' In this respect it is interesting to note that Friesen et al have described hyperplasia of G-cells in the antral mucosa of members of MEN I-families in association with the development of clinical endocrinopathies. ${ }^{89}$ This

Address for correspondence: Prof dr C B H W Lamers, Dept of Gastroenterology and Hepatology, University Hospital: Building 1, C4-PO15, PO Box 9600,2300 RC Leiden, The Netherlands.

Received for publication 9 May 1988. finding may indicate that hypergastrinaemia of antral origin could be a distinct phenotypic manifestation of the MEN I-gene. Furthermore, antral G-cell hyperplasia and raised serum gastrin concentrations have been described in hyperparathyroidism, ${ }^{101.13}$ while antral G-cell hyperplasia has also been reported in patients with acromegaly, ${ }^{10}$ disorders that can be components of the MEN I syndrome.

The present study was undertaken to characterise G-cell function in patients who were obligate carriers of the MEN I-gene, as determined by their being members of families with well characterised MEN-I and also having evidence of hyperparathyroidism.

\section{Methods}

PATIENTS

The subjects consisted of 20 patients with hyperparathyroidism originating from six families with MEN I. Family members who had undergone prior gastric surgery were excluded from this study. The patients and families were ascertained in a population genetic study of 10 Zollinger-Ellison patients (for the complete pedigrees, see ref 6). In that study a total of 109 family members, including all living first 
Table Serum gastrin responses to secretin, bombesin and feeding in 20 hyperparathyroid patients from MEN I-families

\begin{tabular}{|c|c|c|c|c|c|c|c|c|c|}
\hline & & Sex & Age (yr) & $\begin{array}{l}\text { Serum calcium } \\
(\mathrm{mmol} / \mathrm{l})\end{array}$ & $\begin{array}{l}\text { Basal gastrin } \\
(\mathrm{pg} / \mathrm{ml})\end{array}$ & $\begin{array}{l}\Delta \text { Gastrin } \\
\text { after secretin } \\
(\mathrm{pg} / \mathrm{ml})\end{array}$ & $\begin{array}{l}\Delta \text { Gastrin } \\
\text { after bombesin } \\
(\mathrm{pg} / \mathrm{ml})\end{array}$ & $\begin{array}{l}\Delta \text { Gastrin } \\
\text { after feeding } \\
(\mathrm{pg} / \mathrm{ml})\end{array}$ & $\begin{array}{l}\text { Basal acid } \\
\text { output } \\
\text { (mmol/hr) }\end{array}$ \\
\hline \multirow{20}{*}{ Patients } & 1 & M & 45 & $2 \cdot 69$ & $243-530$ & 288 & 550 & 99 & $19 \cdot 2$ \\
\hline & 2 & M & 45 & $2 \cdot 80$ & $595-1180$ & 705 & 160 & 55 & $71 \cdot 0$ \\
\hline & 3 & $\mathrm{~F}$ & 33 & $2.30 *$ & $340-1050$ & 1100 & 120 & 220 & $43 \cdot 5$ \\
\hline & 4 & $\mathrm{~F}$ & 32 & $2 \cdot 66$ & $380-550$ & 830 & 240 & 52 & $9(0.8$ \\
\hline & 5 & $\mathrm{~F}$ & 55 & $3 \cdot 17^{*}$ & $142-260$ & 298 & 70 & 62 & $15 \cdot 0$ \\
\hline & 6 & $\mathrm{~F}$ & 52 & $2 \cdot 82^{*}$ & $250-300$ & 360 & 145 & 145 & $25 \cdot 4$ \\
\hline & 7 & $\mathrm{~F}$ & 48 & 2.95 & $340-435$ & 300 & 77 & 180 & $15 \cdot 1$ \\
\hline & 8 & $\mathrm{~F}$ & 68 & $2 \cdot 77$ & $35-63$ & 12 & 52 & 75 & - \\
\hline & 9 & $\mathrm{M}$ & 59 & $2 \cdot 78$ & $73-82$ & 11 & - & 387 & - \\
\hline & 10 & $\mathrm{~F}$ & 30 & $2 \cdot 90$ & $28-51$ & 14 & 61 & 77 & - \\
\hline & 11 & M & 30 & $2 \cdot 98$ & $42-56$ & 14 & 62 & 24 & - \\
\hline & 12 & $\mathrm{~F}$ & 34 & $2 \cdot 68$ & $23-53$ & 0 & 76 & 71 & - \\
\hline & 13 & M & 31 & $2 \cdot 81$ & $38-51$ & 10 & 62 & 97 & - \\
\hline & 14 & M & 24 & $2 \cdot 75$ & $24-41$ & 28 & 96 & 155 & - \\
\hline & 15 & M & 20 & $2 \cdot 68$ & $24-34$ & 6 & 69 & 26 & - \\
\hline & 16 & $\mathrm{~F}$ & 48 & $2 \cdot 58^{*}$ & 66 & 42 & - & - & - \\
\hline & 17 & $\mathbf{M}$ & 38 & $2 \cdot 74$ & $39-79$ & 41 & 129 & 45 & $1 \cdot 0$ \\
\hline & 18 & M & 29 & $3 \cdot 00$ & $32-45$ & 7 & 29 & 46 & - \\
\hline & 19 & $\mathrm{~F}$ & 57 & $2 \cdot 84^{*}$ & $44-50$ & 101 & 135 & 126 & 0 \\
\hline & 20 & M & 22 & $2 \cdot 86$ & $26-47$ & 0 & 62 & 60 & - \\
\hline $\begin{array}{l}\text { normal } \\
\text { controls }\end{array}$ & $21-40$ & $11 \mathrm{M}-9 \mathrm{~F}$ & $20-64$ & $2.20-2.55$ & $23-84$ & $0-43$ & $42-209$ & $32-158$ & - \\
\hline
\end{tabular}

*previous parathyroid surgery.

degree relatives over 15 years of age, were screened for endocrine abnormalities. All six patients with evidence of MEN I were found to have relatives with endocrinopathies, while no endocrine abnormalities were found among family members of four patients with isolated Zollinger-Ellison syndrome. ${ }^{6}$ There were 10 men and 10 women, ranging in age between 20 and 68 (Table). Five had been operated on for hyperparathyroidism, and three had recurrent hypercalcaemia. Two had coexisting pituitary tumours documented by sellar radiography and increased serum prolactin (cases 1 and 17), and one had been operated on for insulinoma (case 3 ). A diagnosis of ulcer disease had been established in two patients (cases 3 and 4), epigastric pain without documented ulcers occurred in an additional six (cases 1, 5, 6, 7, 17, 19) and chronic diarrhoea in five (cases 1, 2, 3, 4, 6). Gastric acid secretion was measured in all nine subjects with gastrointestinal complaints (Table). Gastrin cell function was evaluated in the 20 hyperparathyroid members of MEN I families and a control group of 20 healthy subjects by the following studies: (1) repeated measurements of basal serum gastrin concentrations, (2) secretin stimulated serum gastrin as a means of identifying gastrinomas, ${ }^{1+16}$ (3) meal stimulated serum gastrin as an index of the G-cell function of the antroduodenal mucosa, ${ }^{171}$, and (4) bombesin stimulated serum gastrin as an index of the antral G-cell function. ${ }^{14-21}$

Serum gastrin was measured by radioimmunoassay as described previously. ${ }^{161720}$ Secretin, $1 \mathrm{CU} / \mathrm{kg}$ body weight (Karolinska Institute, Stockholm, Sweden), was administered as a slow bolus injection to determine its effect on serum gastrin concentrations..$^{15} 16$ Blood samples were drawn at $-5,0,5,10$, and 15 minutes. For the meal stimulation test of serum gastrin, patients ingested a standard test meal consisting of one slice of bread, $50 \mathrm{~g}$ cheese, one boiled egg, and $200 \mathrm{ml} \mathrm{milk} \mathrm{(} 30 \mathrm{~g}$ protein, $25 \mathrm{~g}$ carbohydrate, and $20 \mathrm{~g}$ fat). Blood was drawn $-5,0,15,30,45,60$, 90 , and 120 minutes. Bombesin-14 (Boehringer Mannheim Biochemicals, Indianapolis, Indiana, USA), $100 \mathrm{ng} / \mathrm{kg}$ body weight, was infused over 20 minutes. Blood was drawn at $-5,0,5,10,15,20$, and 30 minutes. Serum calcium was measured by atomic absorption spectrophotometry. Statistical analyses were performed by Wilcoxon's rank-sum test. The study was done in accordance with the declarations of Helsinki and Tokyo, and informed consent was obtained from all patients.

\section{Results}

Seven of the 20 patients, five women, had basal hypergastrinaemia on all three occasions (cases 1-7 in the Table). There were no significant differences between the hypergastrinaemic and normogastrinaemic patients in age $(44$ (9) $v 38$ (15) years, mean (SD)) or serum calcium $(2.77(0.27) \vee 2.80$ $(0 \cdot 12) \mathrm{mmol} / \mathrm{l})$. One hypergastrinaemic patient (case 
3) was normocalcaemic at the time of study due to prior parathyroid surgery. The serum gastrin response to secretin was significantly greater $(\mathrm{p}<0.01)$ in the patients with basal hypergastrinaemia than in those who were normogastrinaemic (Figs 1,2). The increment above basal was greater than $200 \mathrm{pg} / \mathrm{ml}$ in all seven hypergastrinaemic patients and there was no overlap with the subjects who had normal basal serum gastrin concentrations. The serum gastrin response to secretin in the 13 normogastrinaemic patients was no different from that in the normal control subjects. Among these normogastrinaemic patients, two did not have any increase in serum gastrin after secretin, 10 had a modest increase in gastrin, and one (case 19) had a relatively large increase of $101 \mathrm{pg} / \mathrm{ml}$, corresponding to $230 \%$ of basal value. Gastric acid secretion, however, was normal in this patient (BAO $0 \mathrm{mmol} / \mathrm{h}$, MAO $24.0 \mathrm{mmol} / \mathrm{h}$ ) and CT-scan of the

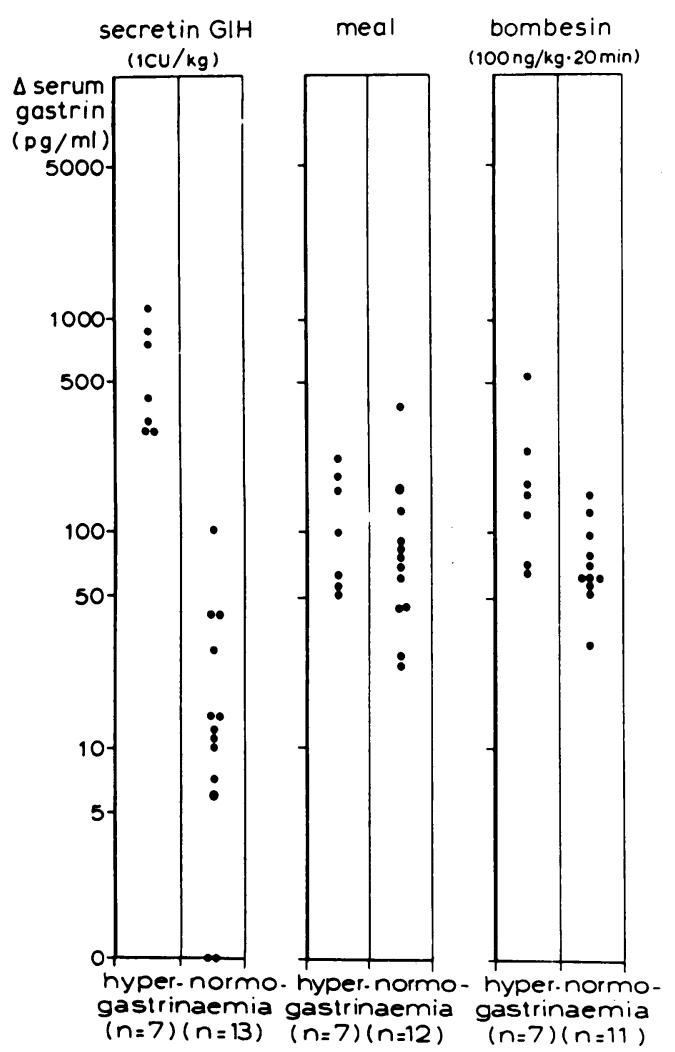

Fig. 1 Serum gastrin responses to secretin, meal and bombesin in hypergastrinaemic and normogastrinaemic patients with hyperparathyroidism from families with multiple endocrine neoplasia type I. The results are depicted on a logarithmic scale. abdomen did not reveal tumours. Serum gastrin concentrations rose in response to the test meal in all 19 subjects studied (Figs 1,2) There was no significant difference between the hyper and normogastrinaemic patients in the absolute postprandial rise in gastrin and the normal control group (Fig. 1). When expressed as percentage change over basal, the patients with basal hypergastrinaemia had a significantly $(\mathrm{p}<0.01)$ lower increase (Fig. 2$)$, but there was considerable overlap between the groups. Case 9 is of particular interest because of the markedly exaggerated serum gastrin response to feeding (Table). Bombesin infusion induced an increase in serum gastrin in all patients studied. The mean increase was significantly greater $(\mathrm{p}<0.02)$ in the hypergastrinaemic patients (Fig. 1), but when the results were expressed as percentage of basal, the hypergastrinaemic patients had a significantly lower $(\mathrm{p}<0 \cdot 01)$ percentage increment in serum gastrin after bombesin (Fig. 2).

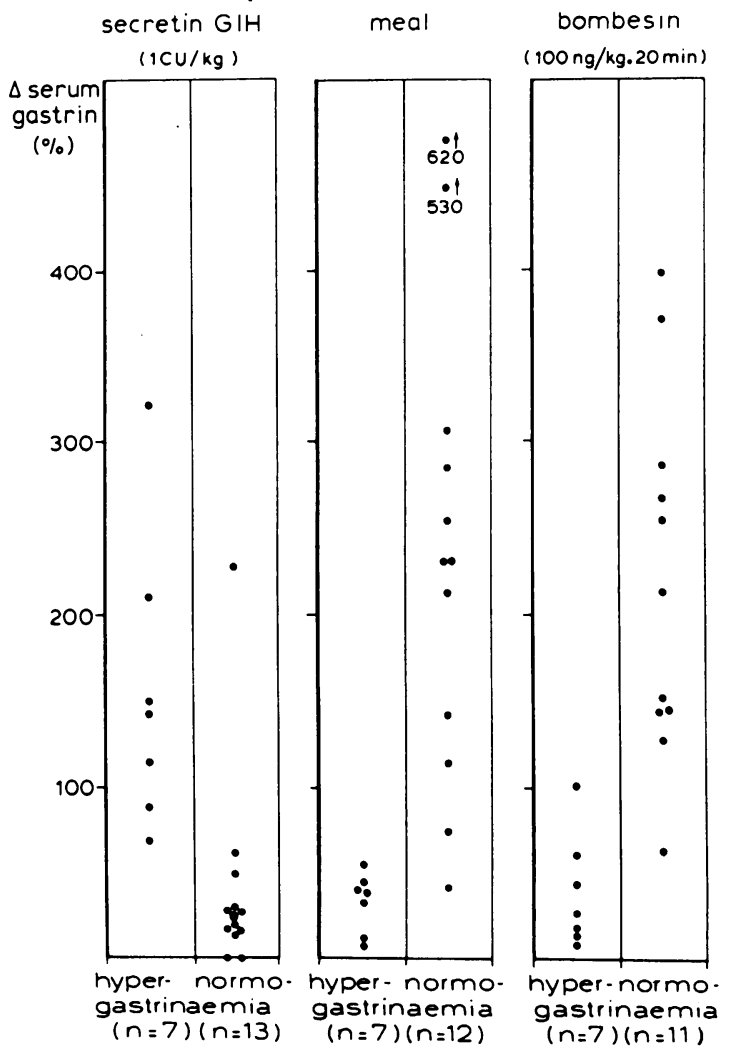

Fig. 2 Serum gastrin responses to secretin, meal or bombesin, expressed as percentage increases over basal value, in hypergastrinaemic and normogastrinaemic patients with hyperparathyroidism from families with multiple endocrine neoplasia type I. 


\section{Discussion}

This is the first report in which G-cell function was evaluated in MEN I-patients by comparing serum gastrin responses to three different stimuli - that is, secretin, food and bombesin. Measurement of serum gastrin is of great importance in patients from MEN I-families, because hyperparathyroidism, present in about $90 \%$ of MEN I-patients, has been reported to be associated with peptic ulcer disease. ${ }^{1122} 23$

The results of this study indicate that in obligate carriers of the MEN I-gene the measurement of basal serum gastrin concentrations is an excellent discriminant between the patients with and without gastrin producing tumours. In seven of the individuals serum gastrin was raised on all three occasions, whereas in the other 13 patients serum gastrin was repeatedly normal. It can be argued that the presence of gastrinomas has not been histologically proven in all seven hypergastrinaemic patients, and that a pancreatic tumour has not definitely been ruled out in the other 13 patients. There was no clinical indication, however, for undertaking laparotomy in these patients. First, because the hypergastrinaemic patients were effectively treated with histamine $\mathrm{H}_{2}-$ receptor antagonists (cimetidine or ranitidine) or omeprazole, obviating the need for total gastrectomy, ${ }^{2425}$ and, second, because it is generally accepted that, because of multiplicity of tumours, attempts to curatively resect the gastrin producing tumours in MEN I-patients are unsuccessful. ${ }^{26}{ }^{27}$ Furthermore, all hypergastrinaemic patients had markedly increased basal gastric acid secretion, whereas such hypersecretion of gastric acid was excluded in the two normogastrinaemic patients with gastric complaints. The results of this study, showing normal basal serum gastrin concentrations in hyperparathyroid patients without gastrin producing tumours, contrast with two recent reports indicating basal hypergastrinaemia in 22 and $25 \%$ of such patients. ${ }^{1213}$ This discrepancy is not because of the characteristics of the gastrin assay used in this study, as it has been shown that the gastrin antiserum used has equal binding to all known sulphated and nonsulphated carboxy-terminal forms of gastrin. ${ }^{16}$ Furthermore, the discrepancy is not due to the fact that in our study only patients with MEN Ihyperparathyroidism were investigated, as we have previously reported normal serum gastrin concentrations in patients with non-MEN I-hyperparathyroidism and in those with non-hyperparathyroid hypercalcaemia. ${ }^{28}$

The serum gastrin increment after secretin was above $200 \mathrm{pg} / \mathrm{ml}$ in all hypergastrinaemic MEN Ipatients, but the response was modest in all but one of the normogastrinaemic patients. In the latter patient, however (case 19) with an increment of 101 $\mathrm{pg} / \mathrm{ml}$ there was not gastric hypersecretion or CTevidence of pancreatic tumours, and serum gastrin concentrations remained normal during a follow up of more than three years. Therefore, this study confirms previous reports indicating that an exaggerated serum gastrin response to secretin is highly specific for gastrin producing tumours in MEN Ipatients with combined basal hypergastrinaemia and hyperchlorhydria.$^{15}{ }^{16}$ In this respect, it is noteworthy that in patients with gastrinoma the serum gastrin response to secretin is influenced by the serum calcium concentration..$^{29.31}$ In fact, acute hypercalcaemia enhances, while acute hypocalcaemia reduces the serum gastrin secretion after secretin provocation in patients with Zollinger-Ellison syndrome. ${ }^{29}$ On the other hand hypercalcaemia induced by infusion of calcium, did not induce false positive secretin provocation tests in peptic ulcer patients without gastrinoma ${ }^{29}$ Furthermore, normalisation of serum calcium by parathyroidectomy in MEN Ipatients with combined hyperparathyroidism and Zollinger-Ellison syndrome diminished secretin induced serum gastrin secretion. ${ }^{30}$ Another interesting finding of the present study is that the absolute amount of gastrin released from the antroduodenal mucosa after a meal is normal in MEN I-patients independent of the presence of hyper- or normogastrinaemia. This is remarkable because a reduced gastrin secretion would have been anticipated in the presence of gastric hypersecretion in the patients with gastrinomas. This finding may indicate an impaired feedback mechanism between gastric acid and antral gastrin secretion in such patients. Skogseid et $a l^{7}$ have studied the serum gastrin response to feeding in a single MEN I-patient with basal hypergastrinaemia, but the large variation in postprandial serum gastrin concentrations precluded a definite conclusion. The present finding of normal postprandial gastrin secretion in the normogastrinemic MEN I-patients is in contrast with the aforementioned study of Skogseid $\mathrm{et} \mathrm{al}^{7}$, showing an enlarged serum gastrin response to feeding in such patients. Analysis of the data, however, shows that in the latter study exaggerated postprandial serum gastrin secretion occurred in only five of the 12 patients studied and that the mean basal serum gastrin concentration in the 'normogastrinaemic' MEN I-patients was significantly higher than in the control group. In this respect it may be interesting to note that the single normogastrinaemic patient with an enlarged postprandial serum gastrin response in the present study (case 9) had a relatively high basal serum gastrin concentration when compared with the other normogastrinaemic patients. In this patient achlorhydria was excluded as the cause of the increased post- 
prandial gastrin secretion by the finding of a slightly raised serum pepsinogen I level of $126 \mathrm{ng} / \mathrm{ml}$. Skogseid $e \mathrm{al}^{7}$ suggested that the exaggerated serum gastrin response to the meal in normogastrinaemic MEN I-patients was caused by islet-cell hyperplasia of the pancreas. Because the serum gastrin response to feeding is accepted to be a reliable measure of the G-cell function of the antroduodenal mucosa, however, antral G-cell hyperfunction is a more likely explanation. ${ }^{17}$ is Antral G-cell hyperplasia has been described by Friesen in a family with the MEN Isyndrome, but this author did not report whether the antral G-cell hyperplasia in antral biopsies was accompanied by an exaggerated postprandial serum gastrin secretion. ${ }^{89}$ This hyperplasia appears to be restricted to certain families and surprisingly appears to occur in both affected and otherwise unaffected members ${ }^{89}$ It should, however, be realised that the diagnosis of antral G-cell hyperplasia, established by G-cell counting of these cells in antral mucosal biopsies, may not accurately reflect overall G-cell function because of the variable size of the antrum and patchy distribution of G-cells. ${ }^{17}$ Antral G-cell hyperplasia has also been described in hyperparathyroidism, ${ }^{10}$ but Skogseid et al found a normal postprandial serum gastrin secretion in four hyperparathyroidism who had no evidence of the MEN Isyndrome. The present study, however, clearly indicates that antral G-cell hyperfunction is not a frequent manifestation of the MEN I-syndrome and thus that neither the MEN I-syndrome per se nor the hypercalcaemia of hyperparathyroidism affects the G-cell function. This finding was supported by the absence of an increased serum gastrin response to infusion of bombesin in the normogastrinaemic MEN I-patients. Because bombesin is reported to release gastrin selectively from the antral and not from the duodenal mucosa ${ }^{19}$ it is suggested to be a more specific stimulus of gastrin secretion by the antral Gcells than a meal. In fact, it has been shown that the serum gastrin response to bombesin can be used to accurately identify hyperfunction and hypofunction of antral G-cells. ${ }^{21}$ The present study, however, indicates that an enlarged serum gastrin response to bombesin is not specific for antral G-cell hyperfunction but also occurs in patients with gastrin producing tumours. It has recently been shown that the gastrin secretion induced by bombesin in patients with gastrinoma is probably because of a direct stimulation of gastrin secretion from the tumour, as bombesin increases gastrin release from gastrinoma cells in longterm culture. ${ }^{31}$

In conclusion, the main findings of the present study were as follows: (i) gastrinoma was the only endocrine disorder in MEN I accounting for abnormal gastrin secretion, (ii) repeated measure- ments of basal serum gastrin could readily identify patients with gastrinoma in MEN I-families, provided that achlorhydria had been excluded, (iii) antral G-cell hyperfunction was not a frequent manifestation of the MEN I-syndrome, and (iv) bombesin was not a specific stimulus of antral gastrin secretion but also released gastrin from tumours in hypergastrinaemic MEN I-patients.

\section{References}

1 Wermer $P$. Genetic aspects of adenomatosis of endocrine glands. Am J Med 1954; 16: 363-71.

2 Wermer P. Multiple endocrine adenomatosis; multiple hormone-producing tumors, a familial syndrome. Clin Gastroenterol 1974; 3: 671-84.

3 Lamers CBHW. Familial multiple endocrine neoplasia type I (Wermer's syndrome). Neth J Med 1978; 21: 270-4.

4 Lips CJM, Lamers CBHW, Vasen JFA. Multiple Endocrine Neoplasia syndromes. Crit Rev Oncol 1984; 2: $117-84$

5 Isenberg JI, Walsh JH, Grossman MI. Zollinger-Ellison syndrome. Gastroenterology 1973; 65: 140-65.

6 Lamers CB, Stadil F, van Tongeren JH. Prevalence of endocrine abnormalities in patients with the ZollingerEllison syndrome and in their families. Am J Med 1978; 64: $607-12$.

7 Skogseid B, Oberg K, Benson L, et al. A standardized meal stimulation test of the endocrine pancreas for early detection of pancreatic endocrine tumors in multiple endocrine neoplasia type I syndrome: Five years experience. J Clin Endocrinol Metab 1987; 64: 1233-40.

8 Friesen SR, Schimke RN, Pearse AGE. Genetic aspects of the ZE-syndrome: prospective studies in two kindred; antral gastrin cell hyperplasia. An Surg 1972; 176: 37082.

9 Friesen SR. The development of endocrinopathies in the prospective screening of two families with multiple endocrine adenopathy. World J Surg 1979; 3: 753-63.

10 Creutzfeldt W, Arnold R, Creutzfeldt C, Feurle G, Ketterer H. Gastrin and G-cells in the antral mucosa of patients with pernicious anaemia, acromegaly and hyperparathyroidism and in a Zollinger-Ellison tumour of the pancreas. Eur J Clin Invest 1971; 1: 461-79.

11 Dent RI, James JH, Wang C, Deftos LJ, Talamo R, Fischer JE. Hyperparathyroidism: gastric acid secretion and gastrin. Ann Surg 1972; 176: 360-9.

12 Strodel WE, Vinik AI, Eckhauser FE, Thompson NW. Hyperparathyroidism and gastroenteropancreatic hormone levels. Surgery 1985; 98: 1101-6.

13 Zaniewski M, Jordan PH, Yip B, Thornby JI, Mallette LE. Serum gastrin level is increased by chronic hypercalcemia of parathyroid or nonparathyroid origin. Arch Intern Med 1986; 146: 478-82.

14 Isenberg JH, Walsh JH, Pasaro E, et al. Unusual effect of secretin on serum gastrin, serum calcium, and gastric acid secretion in a patient with suspected ZollingerEllison syndrome. Gastroenterology 1972; 62: 626-31. 
15 Lamers CB, Buis JT, van Tongeren J. Secretinstimulated serum gastrin in hyperparathyroid patients from families with multiple endocrine adenomatosis type I. Ann Intern Med 1977; 86: 719-24.

16 Lamers CBHW. Clinical usefulness of the secretin provocation test. J Clin Gastroenterol 1981; 3: 255-9.

17 Lamers CBH, Ruland CM, Joosten HJM. Verkooyen HCM, van Tongeren JHM, Rehfeld JF. Hypergastrinemia of antral origin in duodenal ulcer. Am J Dig Dis 1978; 23: 998-1002.

18 Taylor IL, Calam J, Rotter JI, et al. Family studies of hypergastrinemic, hyperpepsinogenemic I duodenal ulcer. Ann Intern Med 1981; 95: 421-5.

19 Basso N, Lezoche E, Materia A, Giri S, Speranza V. Effect of bombesin on extragastric gastrin in man. Am J Dig Dis 1975; 20: 923-7.

20 Jansen JBMJ, Lamers CBHW. Serum gastrin responses to bombesin and food in patients with hypergastrinemia. Dig Dis Sci 1982; 27: 303-7.

21 Jansen JBMJ, Lamers CBHW. Bombesin stimulation test: a novel test for the assessment of the secretory antral function [Abstract]. Gut 1981; 22: A891.

22 Barreras RF. Calcium and gastric secretion. Gastroenterology 1973; 64: 1168-84.

23 Christiansen J. Primary hyperparathyroidism and peptic ulcer disease. Scand J Gastroenterol 1974; 9: 111-4.
24 Van Heerden JA, Smith SL, Miller LJ. Management of the Zollinger-Ellison syndrome in patients with multiple endocrine neoplasia type I. Surgery 1986; 100: 971-7.

25 Lamers CBHW, Lind T, Moberg S, Jansen JBMJ, Olbe L. Omeprazole in the Zollinger-Ellison syndrome. N Engl J Med 1984; 310: 758-62.

26 Passaro E, Stabile BE. Of gastrinomas and their management. Gastroenterology 1983; 84: 1621-3.

27 Deveney CW, Deveney KE. Zollinger-Ellison syndrome (gastrinoma). Surg Clin North Am 1987; 67: 41122.

28 Lamers CBHW, van Tongeren JHM. Serum gastrin response to acute and chronic hypercalcaemia in man. Eur J Clin Invest 1977; 7: 315-7.

29 Jansen JBMJ, Lamers CBHW. Effect of changes in serum calcium on secretin-stimulated serum gastrin in patients with Zollinger-Ellison syndrome. Gastroenterology 1982; 83: 172-8.

30 Norton JA, Cornelius MJ, Doppman JL, Maton PN, Gardner JD, Jensen RT. Effect of parathyroidectomy in patients with hyperparathyroidism, Zollinger-Ellison syndrome, and multiple endocrine neoplasia type I: a prospective study. Surgery 1987; 102: 958-66.

31 Elouaer-Blanc L, Ruszniewski Ph, Mignon M, Duet M, Bonfils S, Lewin MJM. Bombesin stimulation of gastrin release from gastrinoma cells in long term culture. Gastroenterol Clin Biol 1987; 11: 730. 